Title: Good Corporate Governance and Earning Management Practices: An Indonesian Cases

\author{
Author : : Werner R. Murhadi, Dr \\ Affiliation : Faculty of Economics, Universitas Surabaya, Indonesia \\ Address : FE UBAYA, Raya Kalirungkut, Surabaya, Indonesia \\ Phone : +62.31.2981235 \\ Fax. $\quad:+62.31 .2981131$ \\ Email : Werner@ubaya.ac.id \\ Last revision : March, 23, 2009
}




\title{
GOOD CORPORATE GOVERNANCE AND EARNING MANAGEMENT PRACTICES: AN INDONESIAN CASES
}

\author{
Werner R. Murhadi \\ Faculty of Economics, Universitas Surabaya, Indonesia \\ Email: Werner@ubaya.ac.id
}

\begin{abstract}
This research is done for the purpose of finding out the effect of Good Governance practice can reduce earnings management practice done by company. This research uses companies registered in manufacture sector in Indonesia Stock Exchange observation period 2005-2007 as samples. Last sample used in this research is 384 years of observation. This research uses OLS method. The result shows that only two variables have significant effect to Earning Management practice which is CEO Duality and controlling shareholder existence. Other independent variables such as independent commissioner and audit committee and also shareholder coalition outside the controlling shareholder don't have any effect to earning management practice in the company. Control variable like coverage analyst and debt don't have any effect either, to earning management practice existence.

Keywords: Good Corporate Governance, Earnings Management, Coverage Analyst, Debt
\end{abstract}

\section{JEL Classification Code: G34;}

\section{Research Background}

This research focused on earning management, because there are many arguments that says whether it can be considered as a rightful action, or a manipulation on the real business activity. According to Healy and Wahlen (1999) earning management occurred when a manager used his/her consideration in his/her financial report which can cause mislead to company's stakeholder about the basic condition of the company. Some studies show the possibility of managements intervention in the process of financial report making, not only 
through estimation and accounting methods used for the report, but also on operational decision. Healy and Wahlen (1999), Fudenberg and Tirole (1995), and also Dechow and Skinner (2000) shows some earning management that can be done by the managers, as faster selling, change product shipping schedule, slowing research and development's expenses and also maintenance's expenses. While Lo (2007) groups earning management in two categories, real earning management as an action that affects cashflow, and accrual management through changes in accounting estimation and policies. The effect from both of earning management caused different cost, real earning management add more cost to company (Roychowdhury, 2006). But, a survey done by Graham et al. (2005) shows that managers tend to use real earning management rather than accrual management. $80 \%$ reduce discretionary expense, $55 \%$ slows down projects, compared to $28 \%$ do backup reduction and only $8 \%$ changes the assumption and accounting policies used. This survey is a contradiction, as real earning management needs more money from the management, but this option is preferred by them. Research done by Bruns and Merchant (1990) and Graham et al. (2005) indicates that management done real earning management more often than accrual management with the consideration that accrual manipulation causes higher risk. Other researcher, Jiraporn et al. (2006) groups earning management to two groups, beneficial earning management and opportunistic earning management. Earning management is considered useful if it can use its policy to communicate private information it has about company's prospect, which can't be seen on the company's financial report history (Arya, Glover, \& Sunder, 2003; Demski, 1998; Subramanyam, 1996; Watts \& Zimmerman, 1986). While earning management is considered opportunistic if manager used his/her policy to maximize his/her benefit by manipulating the facts of his/her revenue (Healy \& Palepu, 1993).

Based on a short explanation above, the next question is what makes the managers do earning management? Healy and Wahlen (1999) states that the 
main motive of the earning management is to create mislead for the information user and to affect the contracts made by company. The one that affected by the earning management is of course the financial report user. This research then explore if there are any earning management practices in the companies listed on Indonesian Stock Exchange and how the Good Corporate Governance (GCG) effects on the earning management practice which can cause bad effect for people.

\section{Literature Review}

Healy and Wahlen (1999), in their article states that earning management is often done by the management to increase compensation and job security. Beside it, earning management is also done to avoid rules breaking in a loan contract, reduce regulatory cost, or increase regulatory benefit (Cornett et al., 2008). Earning management is not only done by the management for their benefit, but also for major shareholder, even though it will cause loss for the minor shareholder. This fit the statement of Laporta et al $(1999,2000)$ that present an argument that the real problem of most big company listed on Indonesia Stock Exchange's agency conflict is to limit the resources usage by the major shareholders (who are the controller shareholder) that can cause loss for the minor shareholder. Johnson et al. (2000) calls it "tunneling" as a mean of resources transfer from the company to major shareholder's benefit. Cheung et al. (2005) done a study about tunneling activities in China that shows there are transaction done between the companies listed in the Stock Exchange with the major shareholder. The research shows that the transaction done by them can cause bad effects to minor shareholders. Jiang et al. (2005) then documented practices done by most of China's company, where major shareholders used company's loan for their own benefit. Tunneling activities happen often in a developing country, country that hasn't applies GCG. If a company really did tunneling, major shareholders will hide the real condition of the company and 
use the information for their own benefit. One of the ways to cover the real condition of company is doing earning management. To reduce earning management activities, GCG need to be applied (Klein, 2002; Warfield, Wild, and Wild, 1995; Dechow, Sloan, Sweeney, 1996; Beasley, 1996).

\section{Good Corporate Governance}

Corporate Governance is a mechanism developed to increase company performance and management's behavior. Some of GCG mechanisms include the existence of independent commissioner, audit committee, no CEO duality, no Top Share (controlling shareholder), and shareholder's coalition in order to face controlling shareholder. GCG mechanisms will be explained shortly below.

1. Independent Commissioner existence

Klein (2002) found out that board of director from independent side can be more effective in supervising action. Cornett et al. (2008) also stated that operation performance and stock return is getting better as independent commissioner increase. Chen et al. (2006) also found out that characteristic of the board is similar to independency, number of meetings and period of executive board charges is related to the fraud level in a company. While then, Liu and Lu (2007) states that a board structure is not only act as a controlling mechanism in the process of making financial report, but also prevent controlling shareholder to do activities that can cause loss to the other shareholder. In Indonesia (Siregar and Utama, 2008), system that exists in Indonesian's company uses two tier system that consist of commissary board and direction board. The function of commissary board is to watch over the actions of direction board. To prevent loss of minor shareholder, BAPEPAM insist that $30 \%$ of commissary board must be independent and major shareholders.

2. Audit Committee 
Klein (2002) also found out that the existence of audit committee will reduce the earning management practices. In Indonesia, research done by Parulian (2004) in Siregar and Utama (2008) reveal that there are negative relation between discretionary accrual with the audit committee. Klein (2002) states that company that has an audit company can prevent earning management practices done by the management. Jaggi and Leung (2007) research says the same thing. Audit committee can reduce earning management practice in a company with a concentrated owner. Lin (2006) did a research to test the effect of audit committee existence with earning management shows a negative effect, means audit committee can reduce earnings management practice done by the management.

3. CEO Duality

CEO Duality means someone act as a CEO while at the same time, he/she is also the chairman of board. CEO Duality existence will give chances to power concentration which can lead to management discretion. Split CEO will do more effective monitoring (Cornett et al., 2008). This will be different if CEO Duality exists, which can make monitoring action less effective and could lead to high level of discretionary accrual. In Indonesia, this job may not be doubled by direction board and commissary board in the same time, but through nepotism. A lot of Indonesians companies are a family company that grows bigger and then turns into a public company. This is also the cause of the case where parents act as commissary board and his/her children are in direction board, which can lead to management discretion.

4. Top Share

Liu and $\mathrm{Zu}$ (2007) did a research on GCG effects to earning management, and one of the GCG's level appraise is presented by Top Share, major shareholders that become controlling shareholders. The existence of major shareholder that becomes controlling shareholder will cause expropriate to 
minor shareholder. Some of the Corporate Governance Report shows that the bigger dispersion of a company's ownership will make GCG applied better in the company. Claessen et al. (2000) and Fan and Wong (2001) proves that a concentrated ownership especially a single owner will cause GCG application in the company worse, and will lead to more earning management practice.

\section{Shareholder Coalition}

Controlling shareholder existence will drive cheating done by the management and cause loss to other shareholder. But then, the other shareholders can form a coalition to fight against the controlling shareholder. Liu and $\mathrm{Zu}$ (2007) used the similar approach as done by Zingales (1995), use shareholder coalition variable instead of controlling shareholder by grouping nine of ten biggest shareholders, known as Share:2_10, and this variable is a modification of Herfindahl index used to appraise ownership concentration level in a company.

\section{Earning Management}

Ortega and Grant (2003) stated that earning management is possible because there is flexibility in a financial report making in order to change the operational profit of a company. In other words, Abdelghany (2005) explains that earnings management is revenue manipulation done to fulfill the target stated by the management. Lo (2008) then relates earnings management and earnings quality, where a company that did earnings management the most has a bad earning quality. But a company that didn't do earning management doesn't always have good earning quality, because earning quality is affected by many factors. This opinion is supported by Schipper and Vincent (2003) whom states that earning management will affect earning quality. Earnings management often done by companies are (Abdelghany, 2005): 
1. Big Bath, means cost is admitted using one time restructuring charge. This option will cause the company to suffer big expense on cost for this year but it will earn big profit on the next year.

2. Abuse of Materiality, means by manipulating earnings through materiality principal, where there is no specific range about how material a transaction is.

3. Cookie Jar, also known as rainy jar or contingency reserves, means in a good financial condition period, the company can reduce earnings by making more reserves, bigger cost and one write off, vice versa.

4. Round Tripping, back to back and Swap, done by selling an asset/unit to other company with an agreement to buy it back on a fixed price level, and this will help increasing company's revenue.

5. Voluntary accounting changes, done by changing accounting policy used by the company.

6. Conservative Accounting, done by choosing the most conservative accounting method, such as LIFO and adding cost to R\&D rather than capitalize it.

7. Using the Derivative, manager can manipulate earnings through hedging instrument procurement.

The most often used method to appraise the level of earning management done by a company is discretionary accrual method. Earnings have two main component, cash and accounting adjustment known as accrual. The direction and measurement of accrual can be easily manipulated as it is heavily influenced by the management. The total accrual is split to two components, discretionary accrual and non-discretionary accrual. This research will use discretionary accrual modified by Jones (1991) and Dechow, Sloan dan Sweeney (1995). The amount of positive discretionary accrual shows that company indicates increasing income manipulation. In the other hand, negative amount of discretionary accrual indicates decreasing income manipulation. But, the usage 
of discretionary accrual has some weakness (Yu, 2008), and they are: (1) for a company doing merger and acquisition, discontinue in operation and the company that has significant activities abroad will cause accrual usage become inaccurate if it uses balance sheet approach, and (2) discretionary accrual will over estimate a company with an extreme performance, rapid growth and volatile cash flow.

Earnings management can be useful for shareholders if earnings management is used to inform stuffs not included in the company's financial report. Some researches support this statement and called it beneficial earnings management (Subramanyam, 1996). The research done these days, like one done by Arya et al. (2003) shows that organization decentralization often happened, lead to bigger spread of information causing each person has different piece and none has complete information. In this condition, company using earnings management can give more complete information compared to company that doesn't use earnings management. Other research done by Louis (2003) states that company will do stock splits if manager is optimistic on the performance of the company, while manager can use earnings management to show private information to make positive impact on the shareholders. But on the other side, earnings management can also be done by the management to give negative effect on the shareholders by manipulating performance in order to get a job contract and compensation. This might caused agency conflict type I between management and shareholders (Holthausen et al., 1995; DeAngelo, 1988, Dechow dan Sloan, 1991). Controlling shareholder existence condition makes earnings management doable by major shareholders, causes negative effect for public/minor shareholders and lead to agency conflict type II between major and minor shareholders. Usage of earnings management can give benefit for one side by causing loss to another person, known as opportunistic earnings management (Jiraporn et al., 2006). 


\section{Hypothetical Development}

Earnings management practice is possible in Indonesia, considering company ownership in Indonesia tend to be owned by a family and it acts as controlling shareholder. The controlling shareholder can use their influence to management to do earnings management, which then leads to agency conflict type II. If controlling shareholder doesn't exist in the company, earnings management can be done by management, causing loss to shareholders, which then leads to agency conflict type I. One of the ways to reduce earnings management practice is by applying GCG (Klein, 2002; Warfield, Wild, and Wild, 1995; Dechow, Sloan, Sweeney, 1996; Beasley, 1996). From the explanation, major hypothesis are made, and they are:

$\mathrm{H}_{1}$ : Application of Good Corporate Governance can reduce earnings management practice.

Parts of GCG will be explained below as it will form the minor hypothesis:

Independent Commissioner Presences hopefully will be more effective in supervising the management, hoping it will reduce the chance earnings management practice. But the Independent Commissioner should not chosen only to fulfill the rules in Indonesia, because if only to obey the rules, will make the presence of Independent Commissioner become useless. And for that, a minor hypothesis is made:

$\mathrm{H}_{1 \mathrm{a}}$ : Independent Commissioner has negative relation with earnings management practice.

A company with an audit committee will slow down earnings management behavior done by the management. Audit committee presence is expected to found practices that go against free information earlier, so it can reduce earnings management practice. For that, a minor hypothesis is made:

$\mathrm{H}_{1 \mathrm{~b}}$ : Audit Committee has negative relation to earnings management practice. 
CEO Duality existence makes it possible for power concentration which can lead to management discretion. Split CEO will drive better monitoring action (Cornett et al., 2008). This is different if there is any job duality, making monitoring action less effective and closely related to higher level of discretionary accrual.

$\mathrm{H}_{1 \mathrm{c}}$ : CEO Duality existence has positive relation to earnings management practice.

Presence of Top Share, the major shareholders that become controlling shareholder will lead to expropriate to minor shareholders. Some researches have proved that concentrated ownership on a single owner will make GCG application in the company worse, leading to increased earnings management practice.

$\mathrm{H}_{1 \mathrm{~d}}$ : Top Share presence has positive relation to earnings management practice.

Presence of controlling shareholder will drive the major shareholders to cheat and cause loss to other shareholders. But the other shareholders can form a coalition against the controlling shareholder by making a group/shareholders coalition.

$\mathrm{H}_{1 \mathrm{e}}$ : Shareholder coalition outside the controlling shareholder has negative relation to earnings management practice.

This research also use control variable in the form of coverage analyst $(\mathrm{Yu}$, 2008) measured by company measurement proxy (Premuruso dan Bhattacharya, 2008) and company's presence in LQ-45 index, and also debt usage by the company (Premuruso dan Bhattacharya, 2008).

Analyst plays an important role to reveal information for a company. Dyck, morse dan Zingales (2006) shows that the most efficient way for the external to 
know the real condition of the company is by the analyst. While then, Graham, Harvey dan Rajgopal (2005) done survey to 401 financial executive, result on $90 \%$ analyst state the most important group who can influence share price is analyst coverage whom is the second after institution ownership. Healy dan Palepu (2001) also states that information intermediaries such as analyst and ranking company can drive private information to the open and make it possible to detect management's behavior. In this research, analyst coverage is represented by the size of company and companies listed on LQ-45 index. A bigger size company has more information than smaller company because big company tend to be mass media and analyst's main concern, so the bigger a company, earnings management is expected lower (Premuruso dan Bhattacharya, 2008). While then, Camferrman dan Cooke (2002) found a significant relationship between the size and information shared. A bigger company tends to share more information. This research also include companies listed on LQ-45 index as a proxy of the analyst coverage with the consideration that companies listed on LQ-45 index are the most active companies in the stock exchange market, makes more analyst discuss about them rather than companies outside LQ-45 list. This research also include debt usage of the company variable, where a company with high debt will result on higher supervising by the creditor (Premuruso dan Bhattacharya, 2008; Jaggi dan Leung, 2007; Yu, 2008 dan Bartov et al., 2001).

\section{Data and Method}

This research uses all manufacture companies listed in Indonesia Stock Exchange 2005-2007 period as sample with the criteria: (1) Company's data can be accessed completely; (2) List of companies in LQ-45 index during observation is complete, and (3) never had negative equity during observation. Based on these criteria, the number of company that will be take for the sample 
is 128 companies per year. This research using three years observation, so the final number of sample is 384 years of observations.

Earnings management (EM) in this research is done by total accrual (ACC) and discretionary accrual (DACC). Total accrual is defined as the difference of net income and cash flow from operational activities, divided by total assets. Total accrual consists of discretionary accrual and non-discretionary accrual. Discretionary accrual in this research uses Jones (1991) modification to decompose firm level (Total accrual) and uses residual as proxy to discretionary accrual. This can be seen from the formula below:

$$
A c C_{i t} / T A_{i t}=\alpha_{1} \cdot \frac{1}{T A_{i t}}+\alpha_{2} \cdot \frac{\Delta \operatorname{Re} v_{i t}}{T A_{i t}}+\alpha_{3} \cdot \frac{P P E_{i t}}{T A_{i t}}+e_{i t}
$$

As:

Acc $_{\text {it }}$ is Total accrual of $i$ company on $t$ period

$\mathrm{TA}_{\mathrm{it}}$ is Total assets of $\mathrm{i}$ company on $\mathrm{t}$ period

$\Delta \mathrm{Rev}_{\text {it }}$ is the difference of $\mathrm{i}$ company's sales on $\mathrm{t}$ period

$\mathrm{PPE}_{\mathrm{it}}$ is gross property, plant and equipment of $\mathrm{i}$ company on $\mathrm{t}$ period

Then it uses OLS to estimate the value of formula (1), value of dependent variable in Jones' model is normal accrual and the residue is discretionary accrual.

Corporate Governance in this research is measured by these variables below:

1. Independent Board (IB) in this research uses percentage of independent commissioner compared to the total amount of commissioner.

2. Audit Committee presence (AC) uses dummy. 1 means audit committee exists and 0 means audit committee doesn't exist.

3. CEO Duality (Dual) in this research uses dummy data. 1 means CEO Duality exists and 0 means CEO Duality doesn't exist. 
4. Top Share (TS) shows if controlling shareholder are $51 \%$ or more using dummy. 1 if controlling shareholder exists and 0 if controlling shareholder doesn't exist.

5. Share2_5 (S2_5) is defined as five biggest shareholders outside the controlling shareholder. These five shareholders can form a coalition against controlling shareholder. Share2_5's expectation can be measured with the formula:

$$
\text { Share } 2 \_5=\sum_{n=2}^{5}\left(\frac{S_{n}}{S}\right)^{2}
$$

Controlling Variable in this research uses natural Logarithm of asset (ln_asset) to represent size of company, dummy variable of LQ-45 with criteria 1 for company listed in LQ-45 list and 0 for company not listed in LQ-45 list, and also leverage ratio measured as a percentage debt to total company's equity.

To test if earnings management practice really exist, $t$ test is done with the criteria $\mathrm{ACC}=0$ or DACC $=0$ if earnings management doesn't exist. This research will use Generalized Methods of Moments to find out the effect of GCG and control variable to earnings management practice. The research model is developed into a formula (3) below:

$$
\begin{gathered}
\mathrm{EM}_{\mathrm{i}, \mathrm{t}}=\alpha_{1}+\beta_{1} \cdot \mathrm{IB}+\beta_{2} \cdot \mathrm{KA}+\beta_{3} . \mathrm{DUAL}+\beta_{4} \cdot \mathrm{TS} \\
+\beta_{5} . \mathrm{S} 2 \_5+\beta_{6} \text {.ln_asset }+\beta_{7} . \mathrm{LQ} \_45+\beta_{8} . \mathrm{LR}
\end{gathered}
$$

\section{Result and Discussion}

Based on sample's criteria, 384 years of observation obtained as the last sample. To find out if there is any earning management practices occurred, the data is processed to earn the result:

Table 1.

T-test Result

\begin{tabular}{|c|c|c|c|}
\hline Variable & $\mathrm{N}$ & Means & $\mathrm{t}$ \\
\hline
\end{tabular}




\begin{tabular}{|c|c|c|c|}
\hline Accrual & 384 & $-1,6953$ & $-3,304^{*}$ \\
\hline
\end{tabular}

* Signifikan pada $\alpha=1 \%$

From table 1 of data processed, it can be seen that significant t value at $\alpha=$ $1 \%$, which means that at the research period, an earning management practice has occurred with negative mean. This indicates there is a tendency that company records their income smaller than the real cash flow.

Table 2 shows statistic regression after classic assumption test has been done and passed.

Table 2

OLS Results

\begin{tabular}{|c|c|c|c|c|}
\hline Variable & \multicolumn{2}{|c|}{ Without Control Variable } & \multicolumn{2}{|c|}{ With Control Variabl e } \\
\hline Constant & $-0,606$ & $-0,292$ & $-2,574$ & $-0,289$ \\
\hline IB & 0,037 & 1,336 & 0,038 & 1,385 \\
\hline KA & 1,851 & 1,579 & 1,822 & 1,543 \\
\hline Dual & 2,291 & $2,217^{*}$ & 2,361 & $2,263^{*}$ \\
\hline TS & $-2,021$ & $-1,623 * *$ & $-2,102$ & $-1,656^{* *}$ \\
\hline S2_5 & $-0,017$ & $-0,470$ & $-0,018$ & $-0,504$ \\
\hline Ln_asset & & & 0,101 & 0,237 \\
\hline LQ 45 & & & 0,284 & 0,138 \\
\hline LR & & & 0,000 & $-0,553$ \\
\hline R-Squared & \multicolumn{2}{|c|}{0,036} & \multicolumn{2}{|c|}{0,038} \\
\hline $\mathrm{F}$ & \multicolumn{2}{|c|}{$0,016^{*}$} & \multicolumn{2}{|c|}{,072* } \\
\hline $\mathrm{N}$ & \multicolumn{2}{|c|}{384} & \multicolumn{2}{|c|}{384} \\
\hline
\end{tabular}

Note: * Significant at $\alpha=5 \%$

** Significant at $\alpha=10 \%$

Table 2 has 2 results, the first one is without control variable, and the second one is with control variable. Test without control variable will reflect the GCG effect to Earning Management practice. From table 2, F test shows significant result at $\alpha=$ $5 \%$ which means GCG appliance can reduce EM practice. Determinant coefficient shows $3,6 \%$ to EM practice which means GCG appliance can only explain 3,6\% to EM practice. This small value indicates that there many other factors that causes 
company do EM practice, and one of them is the possibility to reduce earning tax paid, as shown in table 1 that states EM practice with negative means. Partially, t test shows that from 5 factor of GCG indicator, only 2 are significant to EM practice, they are CEO Duality (dual) and the existence of controlling shareholder (TS). From the process result shown in table 2, the higher duality of CEO and owner rate that means the owner also roles as the CEO, the higher EM practice rate in the company. This is stated at 1c hypothesis. From table 2, it's also known that the higher controlling shareholder existence rate, the lower EM practice rate. This is contradictive with the hypothesis stated in 1d. The impossible explanation from the result is most of controlling shareholder in Indonesia is institution $(69,60 \%)$ (Murhadi, 2008). This will affect the higher rate of institution ownership that can manage the company professionally to reduce EM practice. The research also found out that the existence of independent commissioner, audit committee and shareholder coalition outside the controlling shareholder don't have significant effect to EM practice. The explanation about no effect from the independent commissioner and audit committee is both of them is appointed by the management, that makes if they don't agree with the management's decision, the company can remove them from their position. While the shareholder coalition outside the controlling shareholder doesn't have the power to join forces and affect EM practice in the company.

From table 2, it's found out that the data processed using additional control variable such as coverage analyst seen from the size of the company and whether the company is listed in LQ-45 index or not, and debt using of the company don't have any significant effect to EM practice in the company. But the GCG variable is consistent whether control variable is used or not. Usage of control variable can only increase determinant coefficient from $3,6 \%$ to $3,8 \%$.

The research done with control variable or without control variable show consistent result. One of the result shows that there are no significant effect from the presence of independent commissioner and audit committee is quite ironic. It must 
be remembered that the presence of independent commissioner and audit committee is to protect the interest of minor shareholders and other stakeholder. The insignificant role of independent commissioner can be explained, that the position of independent commissioner is relatively small in percentage making it not effective to affect decisions made by commissioner board. It gets worse with the condition of Indonesian culture whom felt ashamed to criticize other people. This explanation also works to audit committee who doesn't give any significant effect to the existence of EM practice.

Variable control usage as coverage analyst is expected with a big company and listed in LQ-45 index, that makes the company is observed by public and stock market analyst that can lead to less EM practice done by the company. But the result of this research shows that coverage analyst cannot reduce EM practice in the company. While then, the other control variable, such as debt usage also doesn't give any significant effect. Higher rate of debt usage should have made creditor run a control function toward the company. This can be explained, that the credit given to the company by the creditor mainly in obligation form, is not followed by controlling function from obligation holder toward the company, and this means debt usage cannot reduce EM practice in the company.

\section{Conclusion}

From the result, it's found that GCG practice has a significant effect to EM practice done by the company. But from the five GCG indicators, which are audit committee, independent commissioner, CEO Duality, Top share, and shareholders coalition, only CEO Duality and Top Share have significant effect. Dualisms between the owners who also become the CEO boost the EM practice occurrence. While then, controlling shareholders presence as an institution made controlling activities more professional and result to less EM practice. This research also finds out that coverage analyst and debt usage don't have any effect to reduce EM practice done by the company. Analyst presence and debt usage cannot reduce EM practice done 
by the company. The result also finds out that a lot of Indonesian companies do EM with negative leans. This means company is trying to make their revenue look smaller because they are trying to avoid tax.

\section{References}

Abdelghany, K.E., 2005, Measuring the quality of earnings, Managerial Auditing Journal Vol. 20 No. 9, 2005 p. 1001-1015

Arya, A., Glover, J., \& Sunder, S., 2003. Are unmanaged earnings always better for shareholders?, Accounting Horizons, p. 111-116 (supplement).

Bartov, E., Gul, F.A., Tsui, J.S.L., 2001. Discretionary-accrual models and audit qualifications, Journal of Accounting and Economics 30, p.421-452.

Beasley, M.S., (1996), An empirical analysis of the relation between the board of director composition and financial statement fraud, Accounting Review 71, p.443-465.

Bruns, W., Merchant, K., 1990. The dangerous morality of managing earnings, Management Accounting 72, p.22-25.

Camfferman K, and Cooke T., 2002, An analysis of disclosure in annual reports of U.K. and Dutch companies, J Int Account; 1:28.

Chen, G., Firth, M., Gao, D., Rui, O., 2006. Onwership structure, corporate governance, and fraud: evidence form China, Journal of Corporate Finance 12, p.424-448.

Cheung, Y., Jin, L., Rau, R., Stouraitis, A., 2005. Guanxi, Political Connections, and Expropriation: The Dark Side of State Ownership in Chinese Listed Companies, Working Paper. City University of Hong Kong.

Claessens, S., Djankov, S., Lang, L., 2000. The separation of ownership and control in east Asian corporations, Journal of Financial Economics 58, p.81-112.

Cornett, M.M., A.J. Marcus and H. Tehranian, 2008, Corporate governance and payfor-performance: The impact of earnings management, Journal of Financial Economics 87 p.357-373

DeAngelo, L. E., 1988, Managerial competition, information costs, and corporate governance: The use of accounting performance measures in proxy contests. Journal of Accounting and Economics, 10, p.3-36.

Dechow, P., Skinner, D., 2000. Earnings management: reconciling the views of accounting academics, practitioners, and regulators, Accounting Horizons 14, p. $235-250$.

Dechow, P.M., Sloan, R.G., 1991. Executive incentives and the horizon problem, Journal of Accounting and Economics 14, p.51-89. 
Dechow, P.M., Sloan, R.G., Sweeney, A.P., 1995. Detecting earnings management, Accounting Review 70, p.193-226.

Dechow, P.M., Sloan, R.G., Sweeney, A.P., 1996, Causes and consequences of earnings manipulation: an analysis of firms subject to enforcement actions by the SEC, Contemporary Accounting Research 13, p.1-36.

Demski, J., 1998. Performance measure manipulation, Contemporary Accounting Research, 15, p.261-285.

Dyck, A., Morse, A., Zingales, L., 2006. Who blows the whistle on corporate fraud?, Unpublished working paper, University of Toronto, Canada.

Fan, J., Wong, T., 2001. Corporate ownership structure and the informativeness of accounting earnings in East Asia, Journal of Accounting and Economics 33, p. 401-426.

Fudenberg, D., Tirole, J., 1995. A theory of income and dividend smoothing based on incumbency rents, Journal of Political Economy 103, p.75-93.

Graham, J.R., Harvey, C.R., Rajgopal, S., 2005. The economic implications of corporate financial reporting, Journal of Accounting and Economics 40, p.373.

Healy, P., Wahlen, J., 1999. A review of the earnings management literature and its implications for standard setting, Accounting Horizons 13, p. 365-383.

Healy, P., Palepu, K., 2001. Information asymmetry, corporate disclosure, and the capital markets: a review of the empirical disclosure literature. Journal of Accounting and Economics 31, p.405-440.

Healy, P. M., \& Palepu, K. G. (1993). The effect of firms' financial disclosure policies on stock prices, Accounting Horizons, 7, p.1-11.

Holthausen, R., Larcker, D., Sloan, R., 1995. Annual bonus schemes and the manipulation of earnings, Journal of Accounting and Economics 19, p.29-74.

Jaggi B., and S. Leung, 2007, Impact of family dominance on monitoring of earnings management by audit committees: Evidence from Hong Kong, Journal of International Accounting, Auditing and Taxation 16, p.27-50

Jiang, G., Lee, C., Yue, H., 2005. Tunneling in China: The Surprising Pervasive Use of Corporate Loans to Extract Funds from Chinese Listed Companies, Working paper,Cornell University.

Jiraporn, P., G.A. Miller, S.S. Yoon dan Y.S. Kim, 2006, Is earnings management opportunistic or beneficial? An agency theory perspective, International Review of Financial Analysis, doi:10.1016/j.irfa.2006.10.005

Johnson, S., La Porta, R., Lopez-de-Silanes, F., Shleifer, A., 2000. Tunneling, American Economic Review Papers and Proceedings XC, p. 22-27.

Jones, J., 1991. Earnings management during import relief investigations, Journal of Accounting Research 29, p.193-228.

Klein, A., 2002, Audit committee, board of director characteristics, and earnings management, Journal of Accounting and Economics 33, p.375-400.

La Porta, R., Lopez-de-Silanes, F., Shleifer,A., 1999.Corporate ownership around the world, Journal of Finance 54, p. 471-517. 
La Porta, R., Lopez-de-Silanes, F., Shleifer, A., Vishny, R., 2000. Investor protection and corporate governance, Journal of Financial Economics 58, p. 328.

Lin, J.W., J.F. Li and J.S. Yang, 2006, The effect of audit committee performance on earnings quality, Managerial Auditing Journal Vol. 21 No. 9, 2006 p. 921-933

Lio, Q, and Z. Lu, 2007, Corporate governance and earnings management in the Chinese listed companies: A tunneling perspective, Journal of Corporate Finance 13, p.881-906

Liu, Q., and Z. Lu, 2007, Corporate governance and earnings management in the Chinese listed companies: A tunneling perspective, Journal of Corporate Finance 13 p.881-906

Lo, K., 2008, Earnings management and earnings quality, Journal of Accounting and Economics 45, p.350-357

Louis, H., 2003, Do managers credibly use accruals to signal private information? Evidence from the pricing of discretionary accruals around stock splits, Working paper, Pennsylvania State University.

Murhadi, W.R., 2008, Studi Kebijakan Deviden: Anteseden dan Dampaknya terhadap Harga Saham, Jurnal Manajemen dan Kewirausahaan UK Petra, Vol. 10, No. 1, Maret 2008.

Ortega, W.R. and Grant, G.H. (2003), Maynard manufacturing: an analysis of GAAP-based and operational earning management techniques, Strategic Finance, July, pp. 50-6.

Premuroso, R.F., and S. Bhattacharya, 2008, Do early and voluntary filers of financial information in XBRL format signal superior corporate governance and operating performance?, Int $J$ Account Inf Syst, doi:10.1016/j.accinf.2008.01.002

Roychowdhury, S., 2006, Earnings management through real activities manipulation, Journal of Accounting and Economics 42, p.335-370

Schipper, K. and Vincent, L. (2003), Earnings quality, Accounting Horizons, Annual, p. 97-111.

Siregar, S.V., and S. Utama, 2008, Type of earnings management and the effect of ownership structure, firm size, and corporate-governance practices: Evidence from Indonesia, The International Journal of Accounting 43, p.1-27

Subramanyam, K. R. (1996). The pricing of discretionary accruals, Journal of Accounting and Economics, 22, p.249-281.

Warfield, T.D., Wild, J.J., Wild, K.L., 1995, Managerial ownership, accounting choices, and informativeness of earnings, Journal of Accounting and Economics 20, p. 61-91.

Watts, R., \& J. Zimmerman, (1986), Positive accounting theory, Englewood Cliffs, NJ: Prentice-Hall.

Yu, F., 2008, Analyst coverage and earnings management, Journal of Financial Economics, doi:10.1016/j.jfineco.2007.05.008 
Zingales, L., 1995. What determines the value of corporate votes, Quarterly Journal of Economics 110, p.1047-1107. 